\title{
Editorials Blood transfusion services of the Canadian Red Cross Society
}

The Canadian Red Cross Society has been collecting, processing and distributing blood and blood products in Canada for 43 years. This year over one million units of blood will be collected from three-quarters of a million donors. About 90 per cent of this collected blood will be used as components. Each unit of blood collected in this manner will benefit about two to three patients.

Two programmes within the Canadian Red Cross Society are directly concerned with blood, namely Blood Donor Recruitment and the Blood Transfusion Service (BTS). The BTS, which collects, processes and distributes the blood, is organized in 17 centres across Canada which supply blood and blood products to all Canadian hospitals. The National Office of the Blood Transfusion Service is in Toronto. Assaciated with the National Office is the National Reference Laboratory (NRL), which develops standards that are used in the 17 centres, and serves as a common reference laboratory for special problems. The NRL is also involved in tissue typing, since the Canadian Red Cross supplies all Canadian transplant centres with tissuetyping trays.

The article by Dr. Blajchman et al. which appears in this tissue outlines what components are available and their indications. Information such as this allows the intelligent use of a valuable resource, and furthers our move towards national self-sufficiency. The principles that have governed the Canadian blood programme have been enunciated and affirmed by provincial and federal Ministers of

R.L. Matthews, Professor and Chairman, Department of Anaesthesia, Queen's University, Kingston, Ontario, and Chairman, Blood Transfusion Service Advisory Committee, Canadian Red Cross Society.
Health. These principles are: national self-sufficiency, gratuity of product, voluntary donor system and a non-profit policy.

Canada is self-sufficient in most blood products. Rational use by physicians, surgeons and anaesthetists has helped the programme to achieve this goal.

One of the products in which we are not nationally self-sufficient is Factor VIII. About half of the required amount of Factor VIII for treatment of haemophiliacs in Canada is derived from Canadian plasma. Fresh frozen plasma is required for Factor VIII production. Plasma fractionation is being carried out at present in the United States and at Connaught Laboratories in Toronto. The Rh Institute in Winnipeg and, at a later date, the Armand Frappier Institute in Montreal will also fractionate plasma for Canadians. The decision to support these three fractionation plants in Canada was made in 1980 by the provincial ministers of health, who did not support a proposal that the Canadian Red Cross should undertake fractionation. The Ministers also decided to establish a Canadian Blood Committee, with very broad terms of reference. This Committee has an executive, a secretariat, and a Technical Advisory Committee. The latter is composed of representatives from the various fractionators, a number of professional bodies, such as the Canadian Medical Association, Canadian Hematology Society, Canadian Association of Pathologists and the Canadian Red Cross. The Canadian Anaesthetists' Society has requested membership, without success.

One of the prime responsibilities of the Canadian Blood Committee is budget review. The blood programme will cost an estimated 90 million dollars in 1983, which is about 0.5 per cent of the total health care budget. Most funds for this programme 
come from Federal and Provincial governments. The Canadian Red Cross also contributes 20 per cent of the cost of blood donor recruitment.

The BTS now produces 20 blood products compared with only two in 1947. This has a tremendous impact on the anaesthetist, who must make the judgment as to what volume of crystalloid, stored and/or frozen plasma, platelets and red cells must be used, and when. Anaesthetists must now approach this question of when to replace blood and what component to use from a physiological viewpoint. They can no longer depend upon an isolated laboratory value such as the haemoglobin level. Factors such as the cause of an existing anaemia, the patients' blood volume, the rheological effect of more red cells, and the effect on coagulation and cardiac output must all be taken into account when component therapy is being considered. While some may prefer still to use whole blood in many instances, Dr. Blajchman et al. point out that this is an inefficient use of a valuable donation; it is possible that future generations of anaesthetists will never use a unit of whole blood.

As with any therapy, there are certain hazards and complications associated with transfusion. The total incidence of hepatitis following transfusion with blood and blood products in Canada is not known. Hepatitis screening is performed on all donated blood and plasma, but it is still possible to miss a few carriers. Many mild cases of hepatitis, probably caused by "non-A or non- $B$ " or other viruses, occur and some are missed simply because the patient andior the physician disregards the symptoms. Since less "fresh whole blood" is now used for cardiopulmonary bypass cases, the incidence of cytomegalovirus (CMV) infection, the so-called "post-perfusion syndrome," has decreased

Recently a great deal of attention has been focussed on acquired immunodeficiency syndrome (AIDS). The Centre for Disease Control, Atlanta, defines a case of AIDS as, "a disease at least moderately predictive of a defect in cell mediated immunity occurring in a person with no known cause for diminished resistance to that disease." Some U.S. authorities believe that AIDS is a disease transmittable by blood and blood products and have urged the elimination of high risk groups from their donor panels. The aetiology and clinical epidemiology of AIDS remain poorly defined and the extent of the problem is not yet known.

Canadian anaesthetists are probably responsible for handling more blood products than any other group of physicians. Responsible and intelligent utilization of these products is essential in order to maintain adequate supplies. This has been emphasized in the article by Dr. Blajchman and his colleagues.

In typically Canadian fashion we tend not to appreciate the quality and high standards of our blood programme. It is the envy of many nations. The Canadian Red Cross Society, in co-operation with the medical profession, governments and lay groups, is continually striving to build and improve the Blood Programme and the service it renders to the Canadian public. Anaesthetists can assist this effort by appropriate use of the blood products which the Red Cross provides.

\section{Les services de transfusion sanguine de la Société canadienne de la Croix-Rouge}

La Société canadienne de la Croix-Rouge recueille, traite et distribue le sang et scs dérivés au Canada depuis 43 ans. Cette année, plus d'un million d'unites de sang seront recueillies de trois-quart de millions de donneurs. Environ 90 pour cent du sang recueitli sera utilisé sous forme de dérivés. Il a été établi que chaque unité de sang recueilli de cette façon bénéficiera à environ deux ou trois patients.

Deux programmes à l'intérieur de la Société canadienne de la Croix-Rouge sont directement reliés au sang, soit la division du Recrutement des donneurs et le Service de transfusion sanguine (BTS). Le BTS, qui recueille, traite et distribue le sang, est organisé dans 17 centres à travers le Canada foumissant du sang et des dérivés à tous les 